\title{
PERAMALAN JUMLAH PENGUNJUNG WISATAWAN MANCANEGARA MENGGUNAKAN METODE FUZZY TIME SERIES DI JAWA TIMUR
}

\author{
Arif Latifudin $^{1}$, Dhebys Suryani ${ }^{2}$, Rokhimatul Wakhidah ${ }^{3}$ \\ 1,2,Program Studi Teknik Informatika, Jurusan Teknologi Informasi, ${ }^{3}$ Politeknik Negeri Malang \\ 1 ariflatifudin@gmail.com, ${ }^{2}$ dhebys.suryani@gmail.com, ${ }^{3}$ wakhidah@polinema.ac.id
}

\begin{abstract}
Abstrak
Definisi wisatawan mancanegara adalah setiap orang yang melakukan perjalanan ke suatu negara di luar negara didorong oleh satu atau beberapa keperluan tanpa bermaksud memperoleh penghasilan ditempat yang dikunjungi dan lamanya kunjungan tersebut tidak lebih dari 12 bulan (dua belas bulan) dan tujuan utama pada wisatawan mancanegara ini yaitu (bisnis, berlibur, atau tujuan pribadi lainya). Kunjungan wisatawan mancangara ke Jawa Timur di tahun 2018 sejumlah 830.968 kunjungan bila dibandingan dengan tahun 2017 yang jumlahnya 690.509 kunjungan, terlihat ada pertumbuhan sekitar 20.34\%. Dari jumlah 830.968 kunjungan tersebut yang datang melalu Bandara Internasional Juanda sejumlah 322.965 sedangkan sisanya sejumlah 508.003 kunjungan adalah mereka yang datang ke Jawa Timur melalui darat. Peningkatan kunjungan wisatawan mancanegara ke Jawa Timur harus diantisipasi dengan pembangunan fasilitas yang mendukung kemajuan pariwisata, pembangunan yang dilakukan harus sejalan dengan pertumbuhan kunjungan wisatawan mancanegara ke Jawa Timur. Untuk mengetahui pertumbuhan kunjungan wisatawan mancanegara pada periode berikutnya perlu dilakukan peramalan terhadap kunjungan wisatawan mancanegara ke Jawa Timur. Peramalan yang dibuat pada penelitian ini menggunakan metode Fuzzy Time Series dengan data Januari 2014 - Desember 2018 sebagai data historis untuk meramalkan di periode selanjutnya. Peramalan akan menggunakan metode fuzzy time series menggunakan 60 data sampel diperoleh error sebesar 9.636\% yang diukur menggunakan Mean Absolute Percentage Error (MAPE).
\end{abstract}

Kata kunci: Peramalan,fuzzyfikasi, wisatawan mancanegara, fuzzy time series,MAPE.

\section{Pendahuluan}

Definisi wisatawan mancanegara adalah setiap orang yang melakukan perjalanan ke suatu negara di luar negara tempat tinggalnya, kurang dari satu tahun, didorong oleh suatu tujuan utama (bisnis, berlibur, atau tujuan pribadi lainnya). Kunjungan wisata mancanegara ke jawa timur di tahun 2018 sejumlah 830.968 kunjungan bila dibandingkan dengan tahun 2017 yang jumlahnya 690.509 kunjungan. terlihat ada pertumbuhan sekitar 20.34\%. Dari jumlah 830.968 kunjungan tersebut yang datang melalui Bandara Internasiona Juanda sejumlah 322.965 sedangkan sisanya sejumlah 508.003 kunjungan adalah mereka yang overland (datang ke Jawa Timur melalui darat/datang secara tidak langsung/direct flight internasional).

Peningkatan kunjungan wisatawan mancanegara ke Jawa Timur harus di antisipasi dengan pembangunan fasilitas yang mendukung kemajuan pariwisata. Pembangunan yang dilakukan harus sejalan dengan pertumbuhan kunjungan wisatawan mancanegara ke Jawa Timur. Untuk mengetahui pertumbuhan kunjungan wisatawan mancanegara pada tahun-tahun berikutnya, perlu dilakukan peramalan terhadap kunjungan wisatawan mancanegara ke Indonesia. peramalan merupakan proses menyusun informasi tentang kejadian masa lampau yang berurutan untuk menduga kejadian di masa depan. Peramalan pada umumnya digunakan untuk memprediksi sesuatu yang akan terjadi di masa mendatang. Langkah dalam metode peramalan secara umum yaitu mengumpulkan data, menyeleksi dan memilih data, memilih model peramalan, menggunakan model terpilih untuk melakukan peramalan, evaluasi hasil akhir. (Dewi, 2012).

Peramalan akan menggunakan metode Fuzzy Time Series dengan data januari 2014 - Desember 2018 sebagai data historis untuk meramalkan di periode selanjutnya.

Fuzzy time series merupakan suatu metode peramalan data yang menggunakan prinsip-prinsip fuzzy sebagai dasarnya. Peramalan dengan menggunakan fuzzy time series dapat menangkap pola dari data yang telah lalu kemudian digunakan untuk memproyeksikan data yang akan datang. (Ujianto dan Irawan, 2015)

Peramalan Jumlah Kunjungan Wisatawan Mancanegara di Jawa Timur Menggunakan Metode Fuzzy Time Series,dan mendapatkan Mean Absolute Percentage Error (MAPE) sebesar $9.636 \%$ dengan menggunakan 60 data latih. 


\section{Metodologi}

Konsep fuzzy dasar dikembangkan oleh L. Zadeh yang kemudian dikembangkan oleh Song dan Chissom pada tahun 1993 (Putra, 2017). Proses peramalan dengan menggunakan metode ini tidak membutuhkan suatu sistem pembelajaran dari sistem yang rumit, sehingga mudah untuk digunakan dan dikembangkan. (Brata, 2016) 17 Menurut Song dan Chissom (1994), definisi fuzzy time series dapat digambarkan sebagai berikut:

\subsection{Pembentukan Himpunan Fuzzy}

$D_{1}$ dan $D_{2}$ adalah nilai konstanta yang ditentukan oleh peneliti. $D_{\min }$ adalah data terkecil dari data historis dan $D_{\max }$ adalah data terbesar dari data historis

$$
A=D_{\min }-D_{1} ; D_{\max }+D_{2}
$$

\subsection{Pembentukan Interval}

untuk mengetahui banyak interval dapat mempergunakan rumus Sturges sebagai berikut

$$
\text { Jumlah interval }=1+3.322 \log (n)
$$

dengan,

$\mathrm{n}$ : jumlah data observasi.

Setelah jumlah interval didapat, maka selanjutnya menentukan panjang interval dengan menggunakan rumus sebagai berikut:

$$
\text { Panjang Interval }=\frac{D_{\max }-D_{\min }}{\text { Jumlah Interval }}
$$

Sehingga membentuk sejumlah nilai linguistik untuk mempresentasikan suatu himpunan fuzzy pada interval-interval yang terbentuk dari himpunan semesta $(U)$.

$$
U=\left\{u_{1}, u_{2}, \ldots, u_{n}\right\}
$$

dengan,

$U$ : himpunan semesta

$$
u_{j} \text { : besarnya jarak pada } U \text {, untuk } j=1,2, \ldots, n
$$

\subsection{Mentukan Himpunan Fuzzy}

fuzzy (fuzzy set) adalah sebuah kelas atau golongan dari objek dengan sebuah rangkaian kesatuan (continum) dari derajat keanggotaan(grad of membership). Misalakan $U$ adalah himpunan semesta, dengan $U=\left\{u_{1}, u_{2}, \ldots, u_{n}\right\}$ yang mana $U$ adalah nilai yang mungkin dari $U$, kemudian variabel linguistik $A_{i}$ terhadap $U$ dapat dirumuskan sebagai berikut:
$A_{i}=\frac{\mu_{A_{i}}\left(U_{1}\right)}{n_{1}}+\frac{\mu_{A_{2}}\left(u_{2}\right)}{u_{3}}+\frac{\mu_{A_{i}}\left(U_{3}\right)}{n_{3}}+\cdots+\frac{\mu_{A_{i}}\left(U_{n}\right)}{u_{n}}$

$\mu_{A_{i}}$ adalah fungsi keanggotaan dari fuzzy set $A_{i}$, sedemikian hingga $\mu_{A_{i}}: U \rightarrow[0,1]$. Jika $u_{j}$ adalah keanggotaan dari $A_{i}$, maka $\mu_{A_{i}}\left(u_{j}\right)$ adalah derajat keanggotaan $u_{j}$ terhadap $A_{i}$.

\subsection{Menentukan Fuzzy Logic Relations (FLR) dan Fuzzy Logic Relations Group (FLRG)}

Menentukan FLR dan membuat grup sesuai dengan waktu. FLR $A_{i} \rightarrow A_{j}$ ditentukan berdasarkan nilai $A_{i}$ yang telah ditentukan pada langkah sebelumnya, dimana $A_{i}$ adalah tahun n dan $A_{j}$ tahun $\mathrm{n}+1$ pada data time series. Misalnya jika FLR berbentuk $\quad A_{1} \rightarrow A_{2}, A_{1} \rightarrow A_{1}, A_{1} \rightarrow A_{3}, A_{1} \rightarrow A_{1}$, maka FLRG terbaik yang terbentuk adalah $A_{1} \rightarrow$ $A_{1}, A_{2}, A_{3}$

\subsection{Peramalan}

Jika $F(t-1)=A_{i}$, maka nilai peramalan harus sesuai dengan beberapa aturan berikut yang meliputi: I. Jika FLR dari $A_{i}$ tidak ada $A_{i} \rightarrow \#$, maka $F(t)=A_{i}$

II. Jika hanya terdapat satu $\operatorname{FLR}_{i} \rightarrow A_{j}$, maka $F(t)=A_{j}$

III. Jika $A_{i} \rightarrow A_{j 1}, A_{j 2}, \ldots, A_{j k}$ maka $F(t)=$ $A_{j 1}, A_{j 2}, \ldots, A_{j k}$

\subsection{Defuzzyfikasi}

Misalkan $F(t)=A_{1}, A_{2}, \ldots, A_{n}, \quad$ maka persamaan untuk mencari nilai peramalan akhir adalah sebagai berikut.

$$
\hat{y}(t)=\frac{\sum_{i=1}^{n} m_{i}}{k}
$$

dengan, $\hat{y}(t)$ merupakan defuzzifikasi $\operatorname{dan} m_{i}$ adalah nilai tengah dari $A_{i}$.

Pemberian nomor persamaan menggunakan angka Arab, dituliskan dalam tanda kurung pada posisi rata kanan kolom. Persamaan ditulis menjorok ke dalam sejauh $\pm 10 \mathrm{~mm}$. Persamaan-persamaan yang mebutuhkan tempat lebih dari satu kolom, penulisannya dimungkinkan melintasi 2 kolom.

$$
R(x, y)= \begin{cases}1 & \text { jika } f(x, y)>=T \\ 0 & \text { sebaliknya }\end{cases}
$$

\section{Metodologi Penelitian \\ 3.1 Tahapan Penelitian}

Dalam metodologi penelitian, menjelaskan langkah-langkah yang dilakukan untuk merancang 
sistem. Metodologi penelitian yang dilakukan dalam penelitian ini melalui beberapa tahap, yaitu studi literature, pengumpulan data, analisa dan perancangan, implementasi sistem, uji coba sistem, dan kesimpulan. Tahapan dalam penelitian ini terdapat pada bagan berikut:

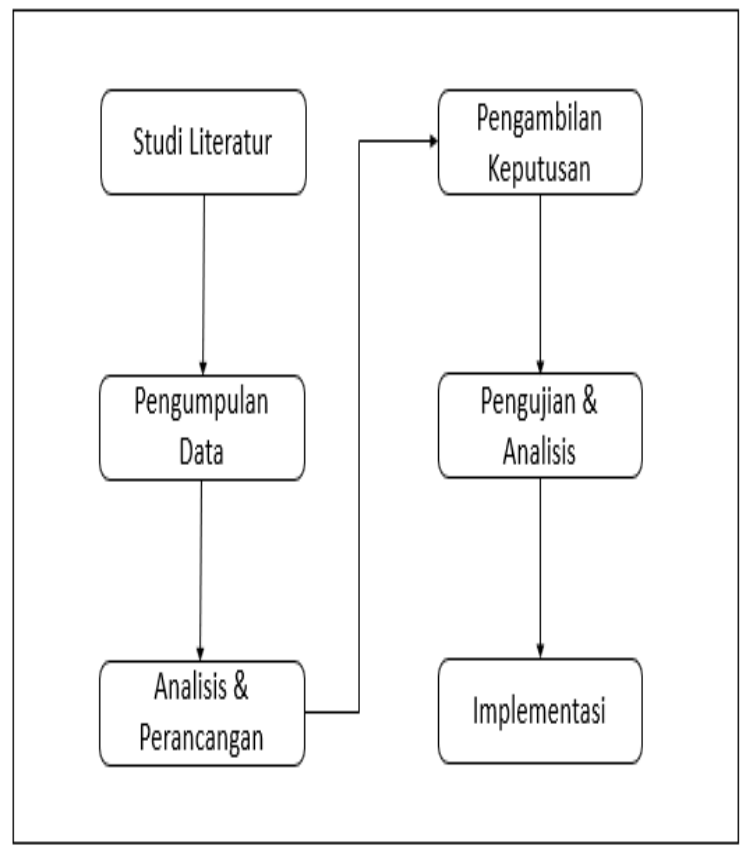

Gambar 1. Tahapan Penelitian

\subsection{Analisis Kebutuhan}

Analisis kebuhan yaitu proses menemukan permasalahan dan menghasilkan alternatif pemecahan yang relevan, tujuan tahap analisis adalah untuk mengetahui kebutuhan pada sistem peramalan wisatawan mancanegara .

Use case diagram adalah satu dari berbagai jenis diagram UML (unifed Modelling Language) yang menggambarkan hubungan inteeraksi antara system dan actor. Pada system peramalan wisatawan mancanegara mengguanakan metode fuzzy time series ini Use Case Diagram menggambarkan alur sistem yang dirancang untuk memenuhi kebutuhan fungsional. Berdasarkan analisis diatas terdapat admin sebagai pengguna dan terdapat 5 (lima) kegiatan di dalam sistem, hubungan antara pengguna melakukan suatu kegiatan tersebut diilustrasikan pada gambar 2 .

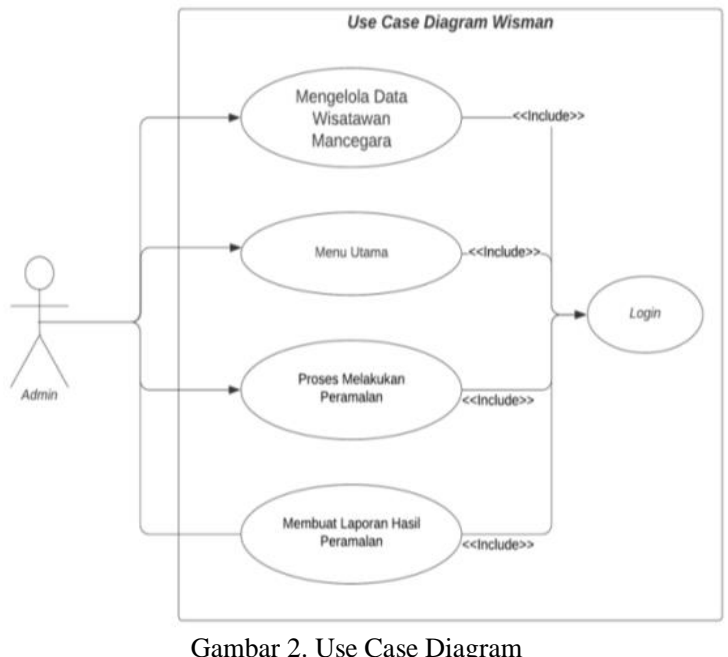

Dari gambar diatas pengguna dapat melakukan hal sebagai berikut : a. Pengguna dapat melakukan akses pada
halaman sistem dengan melakukan login.

b. Pengguna dapat mengelola data wisatawan mancanegara.

c. Pengguna dapat melakukan akses pada halaman utama sistem

d. Pengguna dapat melakukan proses peramalan

e. Pengguna dapat mencetak hasil peramalan

\section{Analasis dan Perancangan Sistem}

\subsection{Gambaran Umum Sistem}

Sistem yang dibangun dalam penelitian ini merupakan sistem untuk melakukan peramalan Pengunjung Wisatawan Mancanegara di Jawa Timur untuk flowchart sistem dapat digambarkan seperti pada Gambar 3 berikut

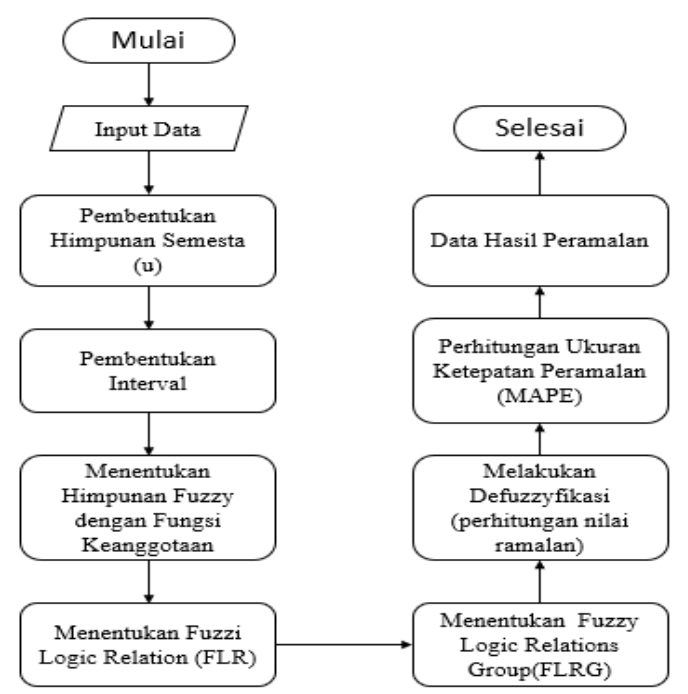

gambar 3. Alur Sistem 


\section{Implementasi Dan Pengujian Sistem}

\subsection{Implementasi Tampilan Sistem}

Pada implementasi ini merupakan hasil antarmuka sistem yang sudah terrealisasikan berikut adalah implementasi antar muka.

a. Tampilan halaman Dashboard

Tampilan pada menu utama terdapat chart hasil dari peramalan yang menggambarkan grafik nilai yang didapatkan seperti pada gambar di bawah ini :

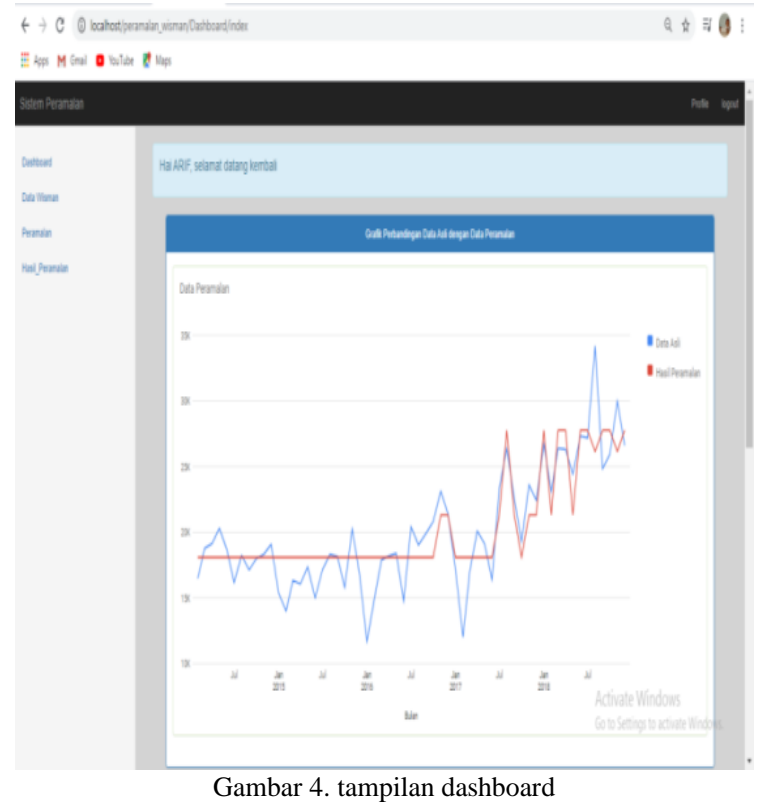

b. Tampilan halaman Data Wisman

Pada halaman data wisatawan merupakan data jumlah kunjungan wisatawan Jawa Timur yang digunakan untuk proses peramalan pada sistem peramalan ini, berikut adalah tampilan halaman data wisatawan yang terdapat pada Gambar dibawah ini:
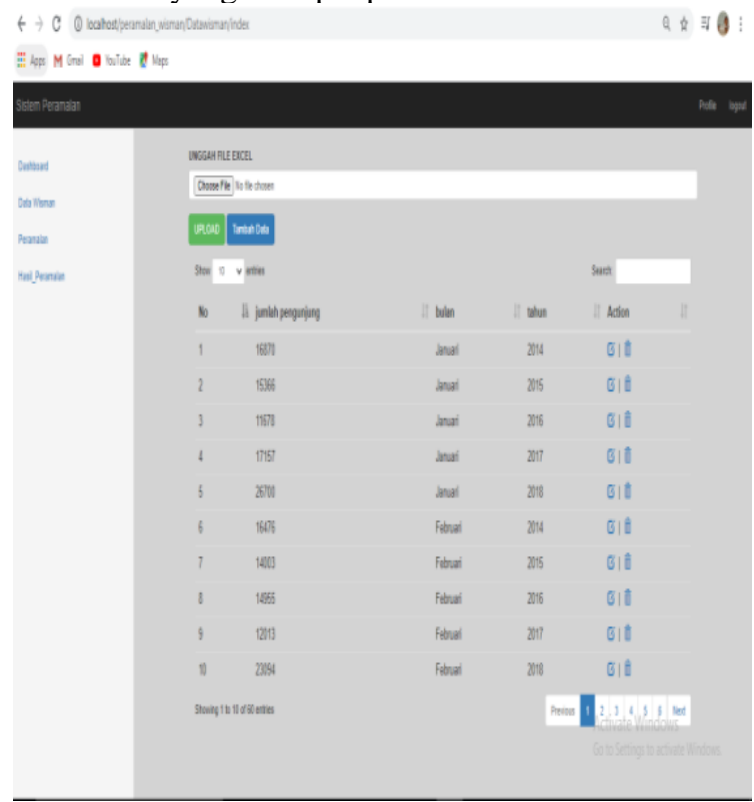

Gambar 5. tampilan data wisman c. Tampilan Proses Peramalan

Pada halaman proses peramalan merupakan tahapan proses peramalan sistem terhadap jumlah kunjungan wisatawan mancanegara di Jawa Timur, berikut adalah tampilan halaman proses peramalan yang terdapat pada Gambar 6.

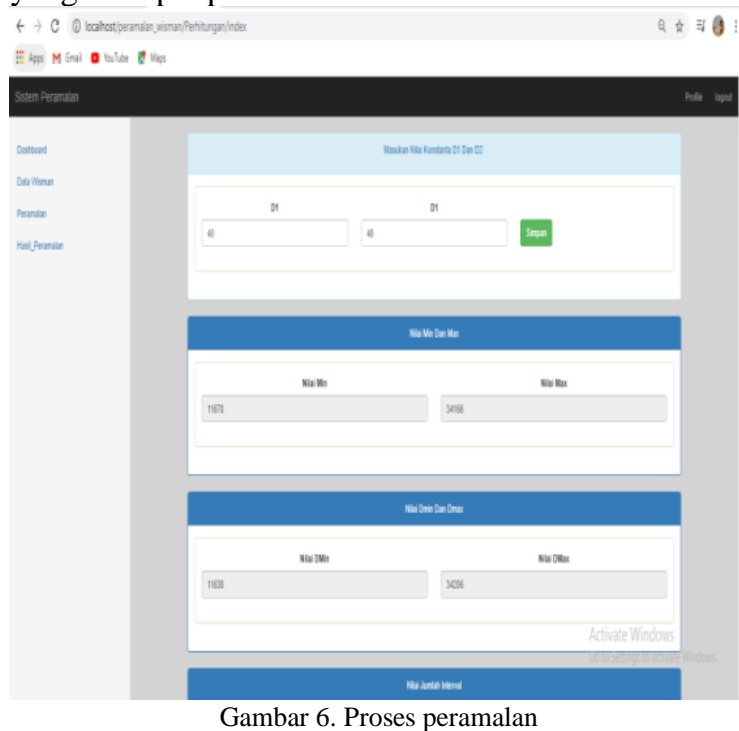

d. Tampilan Hasil peramalan

Pada halaman Hasil peramalan merupakan rangkuman dari hasil proses peramalan terhadap kunjungan wisatawan mancanegara di Jawa Timur yang bisa dijadikan laporan untuk dicetak, berikut adalah tampilan halaman hasil peramalan yang terdapat pada gambar 7 .

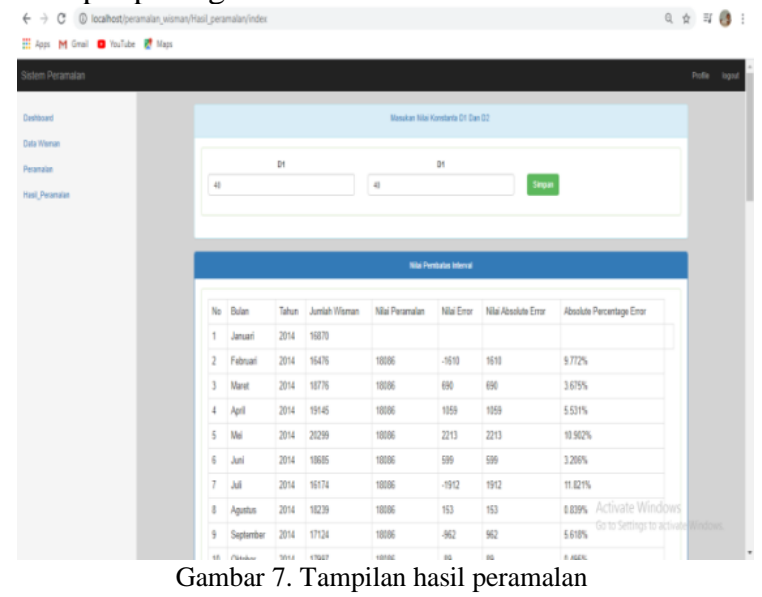

\subsection{Pengujian Akurasi Sistem}

Berdasarkan hasil peramalan yang didapatkan dari perhitungan dan pengujian MAPE, berikut adalah gambar 8 pengujian sistem. 


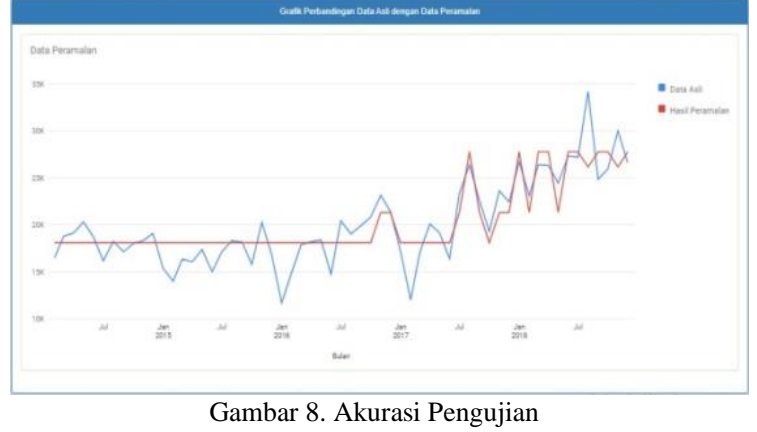

\section{Kesimpulan Dan Saran 6.1 Kesimpulan}

Penggunaan Fuzzy Time Series telah banyak membantu dalam kegiatan peramalan baik dalam berbagai kegiatan science maupun ekonomi, penggunaan Fuzzy Time Series dapat diimplementasikan disemua kegiatan peramalan yang membutuhkan analisa data yang akan segera dipergunakan dalam rangka proses pengambilan keputusan, FTS banyak dipergunakan dalam proses kegiatan peramalan karena memiliki keunggulan dalam bidang, Membantu proses prediksi maupun peramalan dimana data historis tidak dalam bentuk angka real, namun disajikan berupa data linguistic.

Metode FST telah banyak dikembangkan menjadi suatu bentuk model yang efektif dalam proses peramalan berdasarkan data time series. FST memiliki tingkat akurasi yang baik dan dapat dikombinasikan dengan pendekatan lain dalam menyelesaikan masalah peramalan/prediksi.

Peramalan yang dibuat pada penelitian ini menggunakan metode Fuzzy Time Series dengan data Januari 2014 - Desember 2018 sebagai data historis untuk meramalkan di periode selanjutnya. Peramalan akan menggunakan metode fuzzy time series menggunakan 60 data sampel diperoleh error sebesar 9.636\% yang diukur menggunakan Mean Absolute Percentage Error (MAPE).

\subsection{Saran}

Proses peramalan pada penilitian ini hanya menggunakan satu metode yaitu fuzzy time series , untuk penelitian peramalan selanjutnya dapat dilakukan perbandingan antara metode fuzzy time series dengan metode lain untuk membandingkan tingkat keakurasianya.

\section{Daftar Pustaka:}

Admirani, I. (2018). Penerapan Metode Fuzzy Time Series untuk Prediksi Laba pada Perusahaan. Jurnal Penelitian Ilmu dan Teknologi Komputer, 10(1), 19-31. https://doi.org/10.5281/zenodo.3408507
Billy Waworuntu, Johny Lumolos, M. M. (2017). Efektifitas Program Tiff (Tomohon International Flower Festival) Dalam Pengembangan Pariwisata Di Kota Tomohon. Fakultas Ilmu Sosial Dan Politik Universitas Sam Ratulangi, 2.

Cynthia, E. P. (2019). Metode Fuzzy Time Series Cheng Dalam Memprediksi Jumlah Wisatawan Di Provinsi Sumatera Barat. Journal of Education Informatic Technology and ..., 1123.

http://ejurnal.umri.ac.id/index.php/JeITS/articl e/view/1222

Delfanti, R. L., Piccioni, D. E., Handwerker, J., Bahrami, N., Krishnan, A. P., Karunamuni, R., Hattangadi-Gluth, J. A., Seibert, T. M., Srikant, A., Jones, K. A., Snyder, V. S., Dale, A. M., White, N. S., McDonald, C. R., Farid, N., Louis, D. N., Perry, A., Reifenberger, G., von Deimling, A., ... Papers, G. (2018). Metode Fuzzy Time Series Dengan Menggunakan Orde Tinggi Pada Peramalan Nilai Impor Komoditas Hasil Pertanian. Jurusan Statistika Fakultas Matematika Dan Ilmu Pengetahuan Alam Universitas Isalam Indonesia Yogyakarta, 372(2), 2499-2508. https://doi.org/10.1056/nejmoa1407279

Desmonda, D., Tursina, T., \& Irwansyah, M. A. (2018). Prediksi Besaran Curah Hujan Menggunakan Metode Fuzzy Time Series. Jurnal Sistem dan Teknologi Informasi (JUSTIN), 6(4), 141. https://doi.org/10.26418/justin.v6i4.27036

Fyanda, D. A., Ula, M., \& Asrianda. (2017). Implementasi Fuzzy Time Series Pada Peramalan Penjualan Tabung Gas LPG di UD. Samudera LPG Lhokseumawe. Jurnal Sistem Informasi ISSN, 1(1), 1-25.

Kusumadewi, F. (2014). Peramalan Harga Emas Menggunakan Feedforward Neural Network Dengan Algoritma Backpropagation. Program Studi Matematika Fakultas Matematika Dan Ilmu Pengetahuan Alam Universitas Negeri Yogyakarta, 8(33), 44.

Lintang Afdianti Nurkhasanah, Suparti, S. (2015). Perbandingan Metode Runtun Waktu FuzzyChen Dan Fuzzy-MArkov Chain Untuk Meramalkan Data Inflasi Di Indonesia. Jurnal Gaussian, 4, 917-926.

Oliveira, R. (2016). Penerapan Fuzzy Time Series Dalam Peramalan Data Seasonal. Sains Dan Teknologi, 147, 11-40.

Pratama, I. F. F. (2019). sistem informasi manajemen. Journal of Chemical Information and Modeling, 53(9), 1689-1699. https://doi.org/10.1017/CBO9781107415324.0 04

Rahmah, E. H. O., \& Irawan, M. I. (2019). Penerapan Fuzzy Time Series Dalam Peramalan Nilai KWH Listrik Golongan Tarif Rumah Tangga di 
Jawa Timur. Jurnal Sains dan Seni ITS, 8(1). https://doi.org/10.12962/j23373520.v8i1.4210 9

Sommerville, I. (2016). Software engineering (10th edition). In Pearson Education Limited.

Song, Q., \& Chissom, B. S. (1993). Forecasting enrollments with fuzzy time series. Fuzzy Sets and Systems, 54(1), 1-9. https://doi.org/10.1016/0165-0114(93)90355$\mathrm{L}$
Zadeh, L. A. (1988). Fuzzy Logic. Computer, 21(4), 83-93. https://doi.org/10.1109/2.53

Stevenson, W. J. (2015). Operations Management, twelfth Edition. 